\title{
Neoliberal Sağlık Politikalarının Etkinlik Analizi
}

\section{Fatoş ÖCAL ${ }^{1}$}

\section{Efficiency Analysis of Neoliberal Health Policy}

\section{ARTICLE INFO}

\section{Article History:}

Date Submitted:18.09.2016

Date Accepted: 27.12.2016

\section{JEL Classification:}

H5 1

H55

I10

I18

Keywords:

Social Security Reform

Neoliberal Health Practices

Transformation in Health Industry. \begin{abstract}
Multinational companies started to have important effects on the global economic system with the globalization process, thus the countries face with various problems in their social security systems. The companies have pursued jobless growth policies because of the principle of cost minimization and searching for the cheap labor force, have caused the decreases in real wages. This process has came with different practices, not only in economics in general, but also in the health sector. Most of the countries have forced in to do some reforms in their social security systems, which have to compatible with the economic logic of neoliberalism.

According to Turkey's social security reform in the year 2003, the system has to provide equal, preventive, curative, and higher quality health services to the people. On the other hand the system, also has to "make easier the daily life of the people", which is essential. This study aims to analyze the efficiency and also productivity of the practices of the Turkey's social security system in this point of view.
\end{abstract}

\footnotetext{
${ }^{1}$ Ordu Üniversitesi Çalışma Ekonomisi ve Endüstri İlişkileri ABD Yüksek Lisans Öğrencisi
} 


\section{Özet}

Küreselleşmeyle birlikte çok uluslu şirketlerin dünya ekonomik sistemi üzerindeki etkilerinin artması, ülkelerin sosyal güvenlik sistemlerini çeşitli problemlerle karşı karşıya getirmektedir. Şirketlerin maliyet minimizasyonu ilkesi çerçevesinde istihdamsız büyüme politikaları gütmeleri ve çok uluslu şirketlerin öncelikle ucuz işgücü peşinde olmaları reel ücret oranlarında düşüşleri beraberinde getirmiştir. Bu süreç, yalnızca ekonomik alanda değil, sağlık alanında da birçok farklı uygulamayı beraberinde getirmiş ve birçok ülkeyi neoliberalizmin ekonomik mantığıyla uyumlu sosyal güvenlik reformları yapmaya zorlamıştır.

Türkiye sosyal güvenlik sisteminde 2003 yılında gerçekleştirilen reforma göre sistem, nüfusun tümüne eşit, koruyucu, tedavi edici ve kaliteli bir sağlık hizmeti sağlamak zorundadır. Öte yandan bu sistemin "halkın günlük yaşantısını kolaylaştırması” da elzemdir. Bu çalışmanın amacı, Türkiye'de yürütülen bu uygulamaların etkinlik ve verimliliğini bu perspektif üzerinden analiz etmektir.

Anahtar Kelimeler: Sosyal Güvenlik Reformu, Neoliberal Sağlık Uygulamaları, Sağl1k Sektöründe Dönüşüm.

\section{Giriş}

Neoliberal süreçte uluslararası sermayelerin önündeki tüm engellerin kaldırılması, devletin para piyasaları üzerindeki etkilerini yıkıma uğratmış ve devlete sadece sermayenin rahat iş yapabileceği ortamların yaratılması yükümlülüğü verilmiştir. Bunlara bağlı olarak devletlerin yerine getirmesi gereken yükümlülükler serbest piyasaya ve sivil toplum örgütlerine devredilmiştir. Devletlerin sağladıkları sosyal güvenlik hizmetleri, sağlık, eğitim gibi sosyal haklar piyasalaşmış ve devlet hizmeti olarak verilen bu haklar özel sektör biçimini almaya başlamıştır (İçli, 2011: 383). Bu piyasalaşma özel hastanelerin yaygınlaşmasına neden olmuştur. Böylelikle 1980'li yılların sonlarına gelindiğinde sağlık sisteminde yeniden yapılanma yoluna gidilmiştir (Kablay, 2011: 55). Bu yeniden yapılanmanın sonucu olarak ülkemizde neoliberal sağlık politikaları uygulamaları görülmeye başlanmıştır. Bu politikalar; 
genel sağlı sigortası (GSS), aile hekimliği uygulaması, tam gün yasası, performansa dayalı ücretlendirme sistemi ve toplam kalite yönetimi (TKY) uygulamaları olarak beş şekilde görülmektedir (Aka vd., 2012: 64-81). Ancak ülkemizde yürütülen neoliberal sağlık hizmetlerine değinmeden önce sağlık hizmetleri tanımını doğru bir şekilde açıklamak bu çalışmanın çizmek istediği yolu daha net anlamamıza yardımcı olacaktır.

Sağlık hizmetleri, insanların sağlıklarının devam ettirilmesi, korunması ve hastalanmaları anında tanı ve iyileştirme amaçlı çalışmalar uygulanarak bireylerin eski sağlıklı durumlarını geri getirmeye ilişkin tüm hizmetleri içinde barındırır (Er, 2011: 10). Sağlık hizmetlerinin nerede, ne zaman ve ne ölçüde kimler tarafindan talep edileceği belirlenememektedir. Sağlık hizmetlerinin ikame edilmesi ve ertelenmesi söz konusu olamayacak kadar önemli olmakla beraber boyutunu hekimler belirlemelidir. Ayrıca sağlık hizmetlerinin piyasalaşması halinde fiyatlarda değişimler yaşanması kaçınılmaz olacaktır ve bu durum bireylerin sağlık konusundaki duyarlığını zayıflatacaktır (Kablay, 2011: 53). Sağlık hizmetleri iki türde görülmektedir. Bunlardan ilkini birinci basamak sağlık hizmetleri olarak tanımlanan koruyucu sağlık hizmetleri oluştururken bir diğerini ise ikinci ve üçüncü basamak sağlık hizmetlerini kapsayan tedavi edici sağlık hizmetleri oluşturur. Bu ayrımın olmasının temel nedeni muhtemelen sağlık kaybı durumunda çok fazla maddi harcamaların yapılması buna ek olarak birey üzerinde önemli psikolojik gerginlik ve streslere yol açmasıdır.

Koruyucu sağlık hizmetleri sayesinde kişilerin ve toplumların karşılaşabileceği riskler en düşük seviyede tutulmak istenmektedir. Bilhassa yayılma ihtimali olan hastalıkların önlenmesi, sadece bireye değil tüm topluma fayda sağlayacaktır. Bu faydanın tüm toplumu kuşatması, finansmanının kamu tarafından karşılanması gibi nedenlerle koruyucu sağlık hizmetlerinin -salt sosyal mal- olduğu söylenebilmektedir. Bu hizmetler birinci basamak sağlık kuruluşlarınca yürütülmektedir ve bu kuruluşlar, ana çocuk sağlığı, aile hekimliği, aile planlaması merkezleri ve verem savaş dispanserleri gibi kurumlardır (Çelikay vd., 2011: 57).

Bir kişi hastalandığı zaman izlenecek yollar şu şekilde izlenilmelidir. Öncelikle hastanın şikâyetlerine ve hastalığın niteliğine göre birinci basamak sağlık hizmetlerinden birisinde tedavi sürecine başlanır. Bu sağlık kuruluşlarında genellikle yatak bulunmamakla beraber hastaların tedavileri ayakta ya da evde yürütülür. Birinci basamak kuruluşlarda 
giderilemeyen ya da ciddi sağlık sorunu olan hastalar ikinci basamak sağlık kuruluşlarından hizmet almalıdırlar. Eğer ikinci basamak sağlık kuruluşlarında da yeterli gelişim kaydedilmezse üçüncü basamak olan üniversite hastaneleri, onkoloji hastaneleri, akıl-ruh ve sinir hastalıkları merkezleri gibi belirli alanlarda uzmanlaşmış olan kuruluşlara başvurmak gerekmektedir (Çelikay vd., 2011: 57).

Sağlık hizmetleri konusunda bir takım açıklamalarda bulunduktan sonra ülkemizde yürütülen neoliberal sağlık politikalarına ve bu politikaların sağlık hizmetleri üzerinde yatarmış oldukları etkileri tartışabiliriz.

\section{Genel Sağlık Sigortası (GSS)}

GSS 2003 reformunda gündeme getirilmiştir ve reformun temel bileşenini oluşturmuştur. Nüfusun tamamına, adil, koruyucu ve tedavi edici sağlık hizmetinin finansmanını sağlamak GSS'nin temel amacıdır. GSS'nin sunmuş olduğu sağlık haklarından faydalana bilmek için reform öncesi dönemde olduğu gibi belirli bir dönem prim ödeme zorunluluğu vardır. Önceki dönemde bu süreler sigortalılık tipine göre 120 gün ila 8 ay arasında değişiklik gösterirken, GSS'den yararlanabilmek için yalnızca son bir yıl içinde toplam 30 gün GSS primi ödenmiş olması yeterlidir. Ayrıca sağlık hizmeti sunucusuna başvurulduğu tarihte kısa ve uzun vadeli sigorta primleri dâhil olmakla beraber prim borcunun bulunmamas1 gerekmektedir (Ekin, 2012: 155-156).

GSS prim ödeme yükümlülügüne göre üç farklı sınıflandırma biçimine tabi tutulmuştur. İlk olarak çalışan bireylerin, çalışma gelirleri üzerinden primlerinin ödenmesiyle GSS kapsamına alınanlar, ikinci olarak çalışmayan ancak prim ödeyerek GSS kapsamına alınanlar ve son olarak ödeme gücü olmamasından kaynaklı primleri devlet tarafından ödenerek GSS kapsamına alınanlar (Alper, 2014: 316) şeklindedir.

5510 sayılı Kanun'a göre, GSS'den faydalanan yurttaşlar ve bakmakla yükümlü olduğu kişiler için genel sağlık sigortasından sağlanacak sağlık hizmetleri ve sunulan diğer haklardan yararlanmak, genel sağlık sigortasından yararlananlar için bir hak, kurum içinse bu hizmet ve hakların finansmanını sağlamak bir yükümlülüktür. Ayrıca kişilere sunulan sağlık 
hizmetleri ve diğer haklar, ödenen primlerin tutarına göre ilişkilendirilmemektedir (Yüksel, 2016: 289).

$\mathrm{Bu}$ sistemin bileşenleri ise birazdan değineceğimiz sağlık hizmeti uygulamalarıdır.

\subsection{Tam gün yasası}

Tam gün yasasının gündeme geliş tarihi neoliberal politikaların ülke sistemine yayılmadan öncesine dayanmaktadır. İlk olarak 1965 tarihinde gerekli hazırlıklar yapılmadan hekimlere yönelik Tam Gün Çalışma Yasası uygulamaları çıkartılmıştır. Gerekli donanım ve hazırlığın yapılamamış olmasından kaynaklı bu uygulamadan vazgeçilmiştir. Daha sonra 1978 tarihinde tekrardan gündeme gelen Tam Gün Yasası yalnızca iki yıl yürürlükte kalmış ve 1980 tarihinde yürürlükten kaldırılmıştır (Er, 2011: 66).

Daha sonraları 2010 tarihinde bir kez daha gündeme gelmiş ve 5947 sayılı kanunla kabul edilmiştir. $\mathrm{Bu}$ kanuna göre sağlık çalışanlarına tam gün çalışma zorunluluğu getirilmiştir. Böylece özel muayenelerin önüne geçilmek istenmiştir. Fakat doktorların 08:0017:00 saatleri arasında çalışıyor olmaları özel muayenehanelerine saat 17:00'dan sonra geçmeleri anlamına geleceği için bu uygulamanın sağlıklı bir şekilde işlevini yerine getirebilmesi şüphelidir. Bir diğer gerekçe ise üniversite hastanelerinde 14:00'dan sonra özel hasta muayenesi uygulamalarının kaldırılmak istenmesidir. Fakat yapılan bu baskılar hekimleri döner sermaye gelirlerini arttırmak amacıyla daha çok performans göstermeye itmiş ve kamu çalışanları mesai saatleri dışında da çalışmaya zorlanmıştır. Bu durumun nihai sonucu olarak kamu hastaneleri, özel işletme mantığına bürünmüştür (Aka vd., 2012: 73).

Soyer (2007) tam gün yasasına yönelik yazısında durumu şu şekilde değerlendirmektedir; Sağlık çalışanlarına iki seçenek sunulmaktadır ya kamuda ya da özelde çalışmak böylelikle vatandaşların kamuda tedavi görebilmek için gittikleri hastanelerden tekrar hekim tarafindan kendi özel işletmesine yönlendirilme durumları ortadan kalkacaktır. Bu güzel ve istenen önemli bir süreçtir. Böylelikle herkese eşit ve adil bir hizmet sunumunun temel adımı atılmış olunmaktadır. Ancak Tam Gün yasasının sunduğu bir diğer unsur çalışanlar üzerindeki denetim mekanizmasıdır. Devlet, çalışanlar üzerinde para 
denetimini sağlayan bir mekanizma olarak Tam Gün yasasını ön görmüştür. Buna göre çalışanın hem kamu sağlık hizmetlerinde hem de özel sektör sağlık işletmelerinde çalışmaları devletin para denetimini zorlaştırmaktadır. Sağlıkta dönüşümün önemli işlevleri arasında yer alan para akışlarını denetleme işlevi de böylelikle yerine getirilecektir.

Daha önce özelde çalışan doktorların mevcut yasa ilan edildikten üç ay sonra faaliyetlerini durdurmaları, eğer faaliyetlerini durdurmazlarsa kamudaki işlerinden istifa edilmiş sayılacakları yasaca belirtilmiş ve doktorları tek kurumda çalışmaya zorlamıştı. Ancak 2014 yılına geldiğimizde bu hüküm iptal edilmiştir. Kısmı olarak iptale uğrayan Tam Gün yasası özel muayene sisteminin önünü kapatmamış, sağlık hizmetlerinin eşit, adil ve hakkaniyete uygun bir biçimde sağlanması açısından etkinliğini kaybetmiştir.

\subsection{Aile Hekimliği}

Aile hekimliği, Dünya Bankası tarafından Türkiye'ye birinci basamak sağlık hizmetleri uygulamalarına bir alternatif olarak önerilmiş ve bu amaçla Türkiye'ye 2004 y1lında 49.4 milyon Euro kredi tahsis edilmiştir (Sayan vd. 2012,182-183). Bu doğrultuda 2004 yılının sonlarına doğru aile hekimliği kanunu yürürlüğe girmiştir. 2005 yılında pilot uygulama yürütülmüş ve 2010 tarihinden itibaren uygulamanın faaliyetleri yurdun tamamında yaygınlaştırılmıştır. Sağlık Bakanlığı tarafından aile hekimliği tanımı "kişilerin sağlık sigortası olup olmamasına bakılmaksızın herkes için tamamen ücretsiz verilen, sağlı̆̆ koruyucu hizmetleri, taramaları, aşılamaları, gezici sağlık hizmetlerini ve evde bakım hizmetini kapsayan bir paket” olarak ifade edilir (Akdağ, 2012: 109).

Reform öncesi aile hekimlerinin önemli görevlerinden birisi kişilerin hastalık ve tedavi konularında gerekli gördükleri zaman ikinci ve üçüncü basamak sağlık hizmetlerine sevk etmeleriydi. Eğer bir kişi aile hekiminin sevki olmadan birinci ya da ikinci basamak sağlık hizmetine başvurursa karşılaşılacak giderlerin \%30 ila \%50'si arasında ki tutar hastalar tarafindan ödenmekteydi (Ataay, 2008:176). Yani ilk olarak hastanın tedavi sürecine aile hekimleri dahil olmakta böylelikle ikinci ve üçüncü basamak sağlık hizmetlerinde yaşanılabilecek yığılmaların önüne geçilmesi aile hekimlerinin ellerindeydi. Ancak 2007 yılına geldiğimizde Sağlık Uygulama Tebliği ile bu sevk zinciri kırılmıştır. Böylelikle hastalar 
diledikleri sağlık basamağına diledikleri zaman başvurabilme hürriyetine sahip oldukları için ikinci ve üçüncü basamak sağlık hizmetlerinde önemli boyutta yığılmalar yaşanmaktadır (Aka vd., 2012: 68).

Aile hekimliği, teorik olarak güzel amaçlar içermesine karşın gerek az önce bahsettiğimiz çelişkili durum gerekse birazdan bahsedeceğimiz bir takım farklı uygulamaları içinde barındırmasından dolayı birçok eleştiriye maruz kalmaktadır. İlk olarak sistemin ücretsizliğini sorgulayarak başlamalıyız. SS ve GSS Kanununa göre sağlık hizmetlerinin tümünde farklı oranlarda olsa da bir şekilde katkı payları ${ }^{2}$ alınmaktadır.

Bir diğer eleştiri ise daha çok tıbbi cihaz sektörüne yeni pazar açılmasına yöneliktir. Her aile hekimliğine tıbbi donanımı kuvvetli sistemlerin sunulduğunu düşünürsek tıbbi cihaz sektörüne ciddi bir pazar açılmış olunur. Üçüncü eleştiri ise bazı vakaların fikir alış verişi ve önemli birikim isteyen konular olmalarından kaynaklıdır. Ancak aile hekimliği uygulamasına baktığımızda doktorların deneyimsiz olmaları durumunda bilgi birikimi açısından yeterli donanım eksikliklerinin bulunması etkin ve verimli bir sağlık hizmeti sunumunun gerçekleşemeyeceği yönündedir (Er, 2011: 183-185). Dördüncü ve en önemli husus ise hekimlerin yardımcı personellerinin bireysel iş akdi temeline dayalı sözleşmeyle çalışıyor olmalarıdır, böylelikle yardımcı personeller kamu görevliliğinin sağladığı güvencelerden mahrum kalmaktadır (Ataay, 2008: 176).

\subsection{Toplam Kalite Yönetimi Uygulaması}

\footnotetext{
${ }^{2}$ Katkı payları sağlık hizmetlerinden yararlanabilmek için genel sağlık sigortası bulunan kişiler tarafından veya bakmakla yükümlü olduğu kişilerce ödenen tutardır. Aile hekimlerine gidildiğinde direk karşımıza çıkmayan muayene katılım bedelleri SGK'dan gelir ve aylık alanlar ile bakmakla yükümlü oldukları kişiler için gelir ve aylıklarından kesilmekle beraber, diğer kişiler için eczanelerce tahsil edilmektedir. Yani kişinin birinci basamak sağlık kurumundan faydalanması ya da ikinci ve üçüncü basamak sağlık kurumundan faydalanması önem arz etmeksizin kişinin eczaneye ilaç almaya gitmesiyle eczacı tarafından katılım payı talep edilmektedir. Ayaktan tedavilerden sağlanan ve SGK'nın ödediği ilaçlar için tüm sigortalı ve hak sahipleri tarafından bir katkı payı alınmaktadır. Bu bedel sigortalının emekli olup olmamasına göre değişim göstererek halen çalışan sigortalılar ve bakmakla yükümlü oldukları kişilerden \%20 oranında bir katkı payı alınmaktadır. Emeklilerde ve emeklilerin bakmakla yükümlü oldukları kişiler içinde katılım payı \%10 oranında uygulanmaktadır. Daha açık bir dille anlatmak gerekirse 10 TL'lik bir ilaç için çalışan sigortalıların 2 TL, emeklilerin ise 1 TL katılım payı ödedikleri ortadadır. Bu bedellerin yanında ayrıca reçete başına ayrı bir bedel daha alınarak her bir reçete için; 3 kutuya kadar (üç kutu dâhil) temin edilen ilaçlar için 3 TL, 3 kutuya ilave temin edilen her bir kutu ilaç için 1TL katılım payı alınmaktadır (www.ailehekimleri.net)
} 
Toplam kalite yönetimi uygulamasının derinine baktığımızda karşımıza kar odaklı bir uygulama olduğu çıkmaktadır. Bu amaçla şirket bünyesinde çalışan tüm personelden müşteri beklentileri doğrultusunda kalite araştırmaları yürütümüne katkıda bulunmalarını böylelikle verimliliği arttırmaları istenmektedir. Üretim boyunca sürdürülen kalite denetimi sorumluluğu çalışanlar üzerinde gerek zihinsel, gerekse bedensel açıdan ciddi yorgunluklara sebep olmaktadır (Şahin, 2011: 275-278). Ancak belirtmek gerekmektedir ki toplam kalitenin hem şirketler üzerinde hem de çalışanlar üzerinde iki farklı etkisi vardır. Sermeye açısından müşteri memnuniyeti ve tüketim artış hızı yükselir ve buna bağlı olarak karlılık oranlarında önemli miktarda artış yaşanır. Ancak emek gücü için bu durum yüksek denetim, baskı, daha çok sömürü, örgütsüzlük gibi önemli durumlar doğurur (Ulutaş-Ünlütürk, 2011: 70).

Daha sonraları endüstriyel üretim sektöründen, hizmet sektörüne aktarılan TKY, sağlıkta dönüşümle beraber kamu hizmetlerinde de benimsenmeye başlanmıştır. Kamu hizmetleri açısından sadece çalışanlara yönelik değil hizmet sunumundan yararlanan halk için de olumsuz sonuçlar doğurmaktadır. Sağlık çalışanları sürekli süreç odaklı ve standartlara uyum konusunda denetim altında tutulduğundan daha verimsiz ve stresli bir hale gelmektedir. Buna ek olarak müşteri memnuniyeti odaklılığı nedeniyle sağlık kalitesi hastaların istekleri doğrultusunda biçimleneceğinden dolayı doktorlar hastaların taleplerine göre ilaç, tetkik ve tedavi yöntemine gitmektedirler. Hastanın arzu ettiği tetkiklerin yapılması ve ilaçların reçeteleşmesi hekimin tetkik, tedavi ve karar süreçlerinde etkinliğini yitirmesine neden olmaktadır (Ulutaş-Ünlütürk, 2011: 70-72). Hastalara müşteri kimliğinin giydirilmesi, işletmelerin temel mantığg olan müşteri her koşulda haklıdır prensibini de sağlık kurumlarına getirmektedir. Hastaların almış oldukları güç bir yerden sonra şiddete dönüşmekte böylelikle hastane personellerinin tamamına karşı saygısızlığın ve şiddetin artmasına neden olmaktadır. Son yıllarda artan hekimlere yönelik şiddet vakalarının nedenlerinden birisi olarak bu durum ön görülebilinir.

\subsection{Performansa Dayalı Ödeme Sistemi}

1961 tarihli 209 sayılı Yasa ile döner sermaye uygulaması yalnızca yataklı tedavi kurumlarının bazı gereksinimlerini karşılamak amacıyla kullanılmıştır. 1981 yılından itibaren üniversite hastanelerinde çalışan akademik ve idari personelin çalıştıkları kurumun elde ettiği 
gelir ve finansal durumuna göre aldıkları ek ödeme sistemidir. 1989 yılına gelindiğinde kurumun döner sermaye gelirlerinden çalışanlara ek ödeme yapılması konusu düzenlenmiştir. Döner sermaye primi uygulamaları 2001 yılında bir başka düzenleme ile birinci basamak sağlık kuruluşlarında da döner sermaye işletmeleri kurularak, buralarda çalışan personellere de ek ödeme yapılmaya başlanmıştır ve döner sermaye tüm sağlık çalışanları için önemli bir yere gelmiştir. 2003 reformu sonrasında, döner sermaye primi uygulaması değiştirilerek Sağlık Bakanlığı hastanelerinde performansa dayalı ödeme sistemi uygulamasına geçilmiştir. 2003 yılında performansa dayalı ek ödeme sistemi, Sağlık Bakanlığı bünyesinde ki hastanelerin ve çalışanların performansını değerlendirmek amacıyla uygulanmaya başlanmış, 2004 yılından itibaren bireysel olarak, 2005 yılından itibaren kurumsal olarak performans değerlendirme kriterleri, 2006 yılından itibaren ise finansal ve yönetim kriterleri de eklenerek performansa dayalı ek ödeme sisteminin kapsamı genişletilmiştir (Akpınar vd., 2013: 170). Performansa dayalı ödeme sistemi 2011 yılından itibaren üniversite hastaneleri içinde uygulanmaya başlanmıştır.

Performansa dayalı ödeme sistemiyle sağlık çalışanları taban maaşlarına ek olarak o ay için baktıkları hasta sayılarına ve uyguladıkları tedavi yöntemlerine göre taban maaşlarına ek ödeme alacaklardır. Sağlık personellerinin maaşları Sağlık Bakanlığı bütçesinden temel maaşlar kaleminden ödenirken performansa dayalı ek ödemeler sigorta sisteminden finanse edilen döner sermayeden ödenmektedir (Aka vd., 2012: 75).

$\mathrm{Bu}$ sistem ile özellikle hekimlerin bir kısmının gelirlerinde önemli bir artış yaşanmış ve sağlık çalışanlarının arasında önemli ölçüde gelir eşitsizlikleri ortaya çıkmıştır. Tam gün kamuda çalışan hekimlerin döner sermaye gelirleri, aylık maaşlarının üzerine çıkmıştır. Uzman hekimlerin maaşlarının yaklaşık 1,5 katı olan döner sermaye gelirleri, pratisyen hekimler için aylık maaşlarına yakın bir düzeydedir. Ancak son yıllarda sağlık çalışanlarının taban maaşları azalmış, ek ödemelerini arttırmak amacıyla daha uzun sürede ve yoğun bir şekilde çalışmak zorunda kalmışlardır. Uzun ve yoğun çalışma temposu altında sağlık çalışanlarının iş kazalarına uğramaları kaçınılmaz bir gerçek olarak karşımıza çıkmaktadır (Önder vd., 2011: 32). Ayrıca belirtmekte fayda var ki bu yoğun ve yorucu tempo altında 
hastalara karşı tahammülsüzlüğün, yanlış ve eksik diyalog sonucu yetersiz ve hatta yanlış tedavi uygulamalarının önü açılmaktadır.

Sağlık Bakanı Dr. Recep Akdağ'ın performansa dayalı ödeme sistemi konusundaki sözleri sistemin işlerliğini açık ve bariz bir şekilde açıklamaktadır. Aile hekimliği sistemi üzerine konuşurken "hekim ne kadar çok hastayı, kişiyi, aileyi kaydetmişse o kadar çok kazanacaktır" sözleri ve ardından ikinci ve üçüncü basamak sağlık hizmetleri için ise "kim hastasını daha çok memnun ediyor ve daha çok hasta celp ediyorsa, kim daha çok muayene yapıyorsa, müdahalede bulunuyorsa, ameliyat yapıyorsa, hasta takip ediyorsa", o sağlık personellerinin performansa dayalı ödeme sistemi üzerinden alacağı katkı payları çok daha yüksek olacaktır. Yapılan açıklamalar göstermektedir ki Sağlık Bakanlığı hasta doktor ilişkisini tamamen metalaştırmış böylelikle doktorların nitelikleri kaybolmuş hastaların ise sağlık hizmetlerinden yararlanan vatandaş konumları hizmet satın alan müşteri konumuna dönüşmüştür.

Türkiye Kamu Hastaneleri Kurumuna Bağlı Sağlık Tesislerinde Görevli Personele Ek Ödeme Yapılmasına Dair Yönetmeliğin 12. maddesine göre, performansa dayalı ek ödemeler aylık dönemler halinde yapılmakta ve ek ödeme tutarı o dönemin yani, o ayın bitiminden sonraki yirmi gün içerisinde personele ödenmelidir. Ödenecek tutarlar hesaplanırken personele ait mesai içi net performans puanının mesai içi dönem ek ödeme katsayısı ile çarpımı sonucunda brüt ek ödeme tutarı bulunmaktadır. Bulunan bu tutar personele ek ödeme olarak ödeme zamanında tahsis edilmelidir. Döner sermaye gelirlerinden ek ödeme alacak eğitim görevlilerine en yüksek devlet memuru aylığının \%410, uzman doktorlara ve uzmanlığını almış diş hekimlerine \%335 oranında, pratisyen ve diş doktorlarına ise \%180 oranlarına kadar ek ödeme yapılabilmektedir.

Performansa dayalı ödeme sistemi doktorları kısa zamanda çok fazla iş yapmaya yöneltmiş böylelikle iş günleri uzamış, hastaya ayrılan süreler kısalmış ve hastayla doktor ilişkisi, doktorlar açısından değişime uğramaya başlamıştır. Bu durumu sadece doktor hasta ilişkisini etkilememekte aynı zamanda sağlık emekçilerinin arasındaki rekabet ve parçalanmayı güçlendirmektedir. Bireysel performansa ve rekabete dayanan ücretlendirme sistemleri gerek çalışanlar arasındaki dayanışmayı kırmakta, gerekse çalışanların birbirlerine 
ve yürüttükleri işlerine yabancılaşmasına neden olmaktadır. Özellikle kişinin temel ücretinde bir gelişme sağlamadığı için emeklilik hayatında kişiye hiç bir getiri de sağlamayacaktır. Ücret tabanlarının aşağı çekilmesi çalışanların birbiriyle yarışmasına neden olmakta ve ortaya çıkan bu rekabet durumu ise hizmetten yararlananları tamamen müşterileştirmektedir (Kablay, 2014: 83-93).

Kablay'ın 2014 yılında bir hastanede yapmış olduğu alan araştırması sonuçlarına göre katılımcıların \%58,8'i mesleki doyum sağlamadığını ifade etmiştir. Mesleki doyum sağlanamamasının mutlak nedeni performansa dayalı çalışmanın getirmiş olduğu yüksek verimlilik artışları hedefleridir. Ayrıca katılımcıların örgütlülük durumları incelendiğinde sadece \%46,3'ünün bir mesleki örgüte veya sendikaya üye olduğunu ortaya çıkarmıştır (Kablay, 2014: 98-99). Bu durumun nedeni ise daha önce değindiğimiz gibi çalışanları yüksek performansa iten sürekli bir yarış halinde olmalarına neden olan TKY ve performansa dayalı ödeme sistemleridir.

\section{Neoliberal Sağlık Politikalarının Bazı Verilere Yansımaları}

Yukarıda Türkiye sağlık sistemi açısından yürütülen neoliberal politikalardan bahsedilmişti. Ancak bu uygulamaların yıllar içinde yaratmış olduğu sonuçlara bakmak yürütülen politikaları daha anlamlı yorumlamamıza neden olacaktır. Öncelikle bakmamız gereken ilk şey yıllar içinde artan nüfus oranlarıdır. Bu doğrultuda artan işlem sayılarının ya da sağlık hizmetlerinde ulaşımın kolaylaşması gibi temel göstergeleri nüfus oranları daha anlamlı kılacağı için Tablo 1'de yıllara göre demografik göstergeler verilmiştir.

Tablo 1: Genel Demografik Göstergeler, Türkiye

\begin{tabular}{|l|c|c|c|c|c|}
\hline & $\mathbf{2 0 0 2}$ & $\mathbf{2 0 1 2}$ & $\mathbf{2 0 1 3}$ & $\mathbf{2 0 1 4}$ & $\mathbf{2 0 1 5}$ \\
\hline Toplam Nüfus & 66.402 .927 & 75.627 .384 & 76.482 .864 & 77.324 .904 & 78.152 .053 \\
\hline $\begin{array}{l}\text { Yıllık Nüfus Artış Hızı } \\
(\%)\end{array}$ & 12,1 & 12,0 & 13,7 & 13,3 & 13,4 \\
\hline $\begin{array}{l}\text { 65 Yaş ve Üzeri Nüfus } \\
\text { Oranı (\%) }\end{array}$ & 6,7 & 7,5 & 7,7 & 8,0 & 8,2 \\
\hline Kaba Doğum Hızı (\%) & 18,6 & 17,2 & 17,0 & 17,4 & 16,9 \\
\hline
\end{tabular}




\begin{tabular}{|l|c|c|c|c|c|}
\hline Kaba Ölüm Hızı (\%) & 6,5 & 5,0 & 4,9 & 5,1 & 5,2 \\
\hline $\begin{array}{l}\text { Toplam Doğurganlık } \\
\text { Hızı (Kadın Başına) }\end{array}$ & 2,1 & 2,1 & 2,1 & 2,2 & 2,1 \\
\hline
\end{tabular}

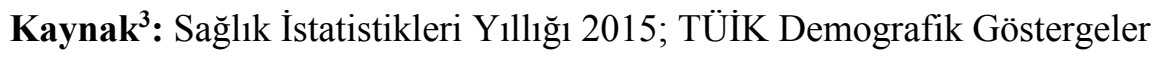

Tablo 1'de görüldüğü gibi nüfus sayısı her yıl artış göstermiştir. Aynı şekilde yaşlı bağımlı nüfus oranının arttığını ve kaba ölüm ${ }^{4}$ hızının 2000'li yıllara göre azalmış olduğunu da tablo 1 bizlere göstermektedir. Bu durum yaşam ömrünün uzadığını, halk sağlığı açısından iyileşmelerin görülüyor olduğu izlenimini vermekle beraber sağlık hizmetlerinin daha etkili ve verimli sunulması gerektiğini de göstermektedir. Artan nüfus hızı aynı artış hızında hekime ve sağlık hizmetlerine gereksinimi de beraber getirecektir. Halk sağlığııı korumak ve yaşanabilecek riskleri önlemek birinci basamak sağlık hizmetlerinin temel görevleri olduğunu hatırlarsak yıllara göre bu sağlık hizmetlerinin sayıları ve etkinlik oranları sağlığın korunması açısından çok önemlidir. Bu nedenle Tablo 2'de bu hizmetlerin oranlarının verilmesi uygun görülmüştür.

Tablo 2: Yıllara Göre Birinci Basamak Kuruluş Sayıları, Türkiye

\begin{tabular}{|l|c|c|c|c|c|}
\hline & $\mathbf{2 0 0 2}$ & $\mathbf{2 0 1 2}$ & $\mathbf{2 0 1 3}$ & $\mathbf{2 0 1 4}$ & $\mathbf{2 0 1 5}$ \\
\hline Să̆̆ık Ocă̆ı & 5.055 & - & - & - & - \\
\hline Aile Hekimlı̆̆i Birimi & - & 20.811 & 21.175 & 21.384 & 21.696 \\
\hline Aile Sağlı̆̆ı Merkezi & - & 6.660 & 6.756 & 6.829 & 6.902 \\
\hline $\begin{array}{l}\text { Toplum Sağlı̆̆ } \\
\text { Merkezi }\end{array}$ & - & 957 & 971 & 970 & 970 \\
\hline Sağlık Evi & 2.899 & 5.691 & 5.594 & 5.572 & 5.544 \\
\hline AÇSAP5 Merkezi & 298 & 189 & 183 & 182 & 182 \\
\hline $\begin{array}{l}\text { Verem Savaş } \\
\text { Dispanseri }\end{array}$ & 277 & 179 & 177 & 179 & 181 \\
\hline $\begin{array}{l}\text { Kanser Erken Teşhis, } \\
\text { Tarama ve Ĕgitim } \\
\text { Merkezi }\end{array}$ & 84 & 124 & 134 & 132 & 156 \\
\hline $\begin{array}{l}\text { 112 Acil Yardım } \\
\text { Istasyonu }\end{array}$ & 481 & 1.863 & 2.072 & 2.186 & 2.323 \\
\hline
\end{tabular}

\footnotetext{
${ }^{3}$ Kaynakta belirtildiği gibi her iki farklı kurumun yayınlamış olduğu bilgilerden faydalanılmıştır ancak her iki kurumun verileri bir biri ile birebir örtüşmemektedir.

${ }^{4}$ Kaba ölüm hızı, bir coğrafyada yaşayan mevcut kişi sayısının o dönem içerisinde yaşanan ölüm sayısına bölünüp 1000 ile çarpılması sonucu elde edilen oranı nitelemektedir.

${ }^{5}$ Ana Çocuk Sağlığı ve Aile Planlaması Genel Müdürlüğü.
} 


\begin{tabular}{|l|l|l|l|l|l|}
\hline $\begin{array}{l}\text { Halk Sağlı̆̆ı } \\
\text { Laboratuarları }\end{array}$ & - & - & 83 & 83 & 83 \\
\hline
\end{tabular}

Kaynak: Sağlık İstatistikleri Yıllığı 2015

Yaşanan nüfus artışına kıyasla tabloda verilen sağlık kuruluşlarında önemli artışlar gözlemlenmemektedir. Özellikle en son elde edilen verilere göre bir yıl içinde yaklaşık olarak 174 bin kişiye kanser teşhisi koyulduğunu (Türkiye Kanser İnsidansları, 2013) göz önüne alırsak Kanser Erken Teşhis Tarama ve Eğitim Merkezi sayılarının ciddi anlamda yetersiz olduğu kanısına rahatlıkla varılmaktadır. 2014 yılı TÜİK verilerine göre kadınların \%75,1'inin hiçbir zaman mamografi çektirmediği anket sonuçlarında ortaya çıkmıştır. Bu durum da bizlere ciddi anlamda önleyici sağlık hizmetleri konusunda yetersiz kalındığını göstermektedir. Bu oranların muhtemelen bu denli düşük kalmasındaki neden 2007 yılında sevk zincirinin kırılması nedeniyle hastaların birinci basamak sağlık kuruluşlarından ziyade ikinci ve üçüncü basamak sağlık kuruluşlarına yönelmelerinden kaynaklanmaktadır. Bu tezimizi daha somut bir hale getirmek amacıyla hekime müracaat oranlarını vermekte yarar vardir.

Tablo 3: Y1llara ve Kurum Türlerine Göre Toplam Hekime Müracaat Sayısı, Türkiye

\begin{tabular}{|l|c|c|c|c|c|}
\hline & $\mathbf{2 0 0 2}$ & $\mathbf{2 0 1 2}$ & $\mathbf{2 0 1 3}$ & $\mathbf{2 0 1 4}$ & $\mathbf{2 0 1 5}$ \\
\hline Sağlık Ocağı & 69.103 .517 & - & - & - & - \\
\hline Aile Hekimliği & - & 221.672 .029 & 212.318 .024 & 214.120 .750 & 208.538 .951 \\
\hline Verem Savaş Dispanseri & 2.012 .458 & 2.143 .765 & 1.815 .805 & 1.643 .937 & 1.495 .558 \\
\hline AÇSAP Merkezi & 2.980 .481 & 630.583 & 536.707 & 660.056 & 548.433 \\
\hline $\begin{array}{l}\text { TSM'ler tarafından } \\
\text { Yapılan Diğgr Muayeneler }\end{array}$ & - & 10.035 .342 & $4 . .999 .980$ & 2.234 .348 & 3.457 .520 \\
\hline Özel Poliklinikler & 731.132 & 655.432 & 582.265 & 546.514 & 523.694 \\
\hline $\begin{array}{l}\text { Birinci Basamak } \\
\text { Toplamı }\end{array}$ & $\mathbf{7 4 . 8 2 7 . 5 8 8}$ & $\mathbf{2 3 5 . 1 3 7 . 1 5 1}$ & $\mathbf{2 2 0 . 2 5 2 . 7 8 1}$ & $\mathbf{2 1 9 . 2 0 5 . 6 0 5}$ & $\mathbf{2 1 4 . 5 6 4 . 1 5 6}$ \\
\hline \begin{tabular}{l} 
Özel Tıp Merkezleri \\
\hline Hastaneler
\end{tabular} & 9.824 .802 & 32.012 .211 & 31.256 .100 & 28.208 .781 & 26.953 .360 \\
\hline $\begin{array}{l}\text { 2. ve 3. Basamak } \\
\text { Toplamı }\end{array}$ & $\mathbf{1 3 4 . 3 1 3 . 6 5 9}$ & 354.636 .935 & 378.812 .243 & 396.577 .644 & 418.581 .931 \\
\hline Genel Toplam & $\mathbf{2 0 8 . 9 6 6 . 0 4 9}$ & $\mathbf{6 2 1 . 7 8 6 . 2 9 7}$ & $\mathbf{6 3 0 . 3 2 1 . 1 2 4}$ & $\mathbf{6 4 3 . 9 9 2 . 0 3 0}$ & $\mathbf{6 6 0 . 0 9 9 . 4 4 7}$ \\
\hline
\end{tabular}

Kaynak: Sağlık İstatistikleri Yıllığı, 2015 
Tablo 3'e baktığımızda 2002 yılından 2015 yılına kadar geçen süre zarfında önleyici ve tanı koyucu birinci basamak sağlık kuruluşlarının pek de söylemde olduğu gibi aktif olarak kullanılmadığını görmekteyiz. Ayrıca aile hekimlerine başvuru oranlarında ise her geçen yıl düşüş eğilimi görülmektedir. Aile hekimliği uygulamasının temel görevlerinden birisi olan ikinci ve üçüncü basamak sağlık hizmetlerinde ki yığılmaları önleme işlevleri de, pratik de pek işler vaziyette değildir. 2. ve 3. basamak sağlık hizmetleri daha çok ciddi rahatsızlıkların tedavi ve araştırılma sürecini bünyesinde barındıran tıbbi donanımı yüksek sağlık birimledir. Ciddi sağlık problemlerinin araştırılma ve tedavisinin yürütümünü sağlayan bu basamaklara halk tarafından önemli bir yönelim olduğu görülmektedir ve bu yönelim doktorlar ile hastalarının daha uzun ve daha ayrıntılı tedavi uygulamalarını engelleyecektir.

Bunun önemli bir sonucu olarak hekimler hafif rahatsızlığı olan hastayla, ağır hastalığı bulunan kişilere eşit sürelerde bakmak zorunda kalmış olacaktır. Bu duruma ek olarak tablo 3'e baktığımızda gerekli yasal düzenlemelerin uygulanmasıyla beraber özel tıp merkezlerine yönelen hasta sayısının da arttığını görmekteyiz. Bu durum bizlere devlet, sermaye iş birliğini göstermektedir. Neoliberal politikaların artması, yasal mevzuatların bu temeller üzerine kuruluyor olması halkın özel sermayeye ulaşımını daha rahat sağlamakta ve bir hak olan sağlık hakkının özel sektörün eline bırakılmasına neden olmaktadır.

Genel olarak 2003 reformuyla önleyici hekimliğin önemi buna ek olarak herkese eşit ve adil sağlık sunumunun gerekliliği gündeme getirilmiş ancak bu gerekliliklerin pratiğe nasıl yansıdığını inceledikten sonra sırada hasta hekim ilişkisinin dönüşümünü inceleyeceğiz.

Sağlık kurumlarında yürütülen performans uygulamalarının hekimleri daha çok işlem yapmaya ve daha çok çalışmaya ittiğinden bahsetmiştik. Bu durumun bir yansıması olarak tablo 4'te yıllara göre yataklı tedavi kurumlarında bazı cihazların toplam görüntüleme sayıları bulunmaktadır. 
Tablo 4: Yıllara Göre Yataklı Tedavi Kurumlarında Bazı Cihazların Toplam Görüntülenme Sayısı, Türkiye

\begin{tabular}{|l|l|l|l|l|}
\hline & $\mathbf{2 0 1 2}$ & $\mathbf{2 0 1 3}$ & $\mathbf{2 0 1 4}$ & $\mathbf{2 0 1 5}$ \\
\hline MR $^{\mathbf{6}}$ & 8.592 .072 & 9.073 .582 & 10.259 .508 & 11.286 .357 \\
\hline BT $^{7}$ & 9.825 .273 & 11.039 .694 & 12.407 .145 & 13.675 .737 \\
\hline Ulturasyon & 22.409 .862 & 24.819 .662 & 27.151 .430 & 27.407 .816 \\
\hline Doppler Ultrasyon & 6.939 .679 & 8.098 .999 & 9.418 .461 & 10.839 .226 \\
\hline EKO $^{8}$ & 5.048 .661 & 5.531 .977 & 6.390 .696 & 6.960 .194 \\
\hline
\end{tabular}

Kaynak: Sağl1k İstatistikleri Y1llı̆̆1, 2012; 2015

Tablo 4'e baktığımızda aklımıza iki soru gelmektedir. Nüfus artış hızı gerçekleşirken önleyici sağlık hizmetlerinin etkin olmamasından kaynaklı olarak hastalık oranlarında da mı bir artış yaşanmaktadır? Ya da hekimlerin işlem sayılarını arttırması amacıyla gerekli ya da gereksiz bir şekilde hastalara bir takım cihaz görüntülenme işlemleri mi uygulamaktadır? $\mathrm{Bu}$ sorunun cevabını bulabilmek için ciddi oranda bir takım çalışmalar yürütülmedir ama nüfus artış hızı göz önüne alınır ve yıllar içindeki yapılan toplam görüntülenme sayısı oranlarındaki artışlar dikkate alınırsa bu oranların önemli düzeyde fazla olduğunu görmekteyiz.

İşlem oranlarındaki artışlardan sonra değerlendirmemiz gereken bir diğer konu ise yıllara göre yapılan toplam ameliyat sayılarıdır. Çünkü hekimlerin önem derecesi çok yüksek bulunmayan rahatsızlıklarda bile hastaları bıçak altına alış oranlarında artışlar yaşandığı düşünülmektedir. Tablo 5 bize bu konuda bilgi verecektir.

Tablo 5: Yıllara ve Sektörlere Göre Toplam Ameliyat Sayıları, Türkiye

\begin{tabular}{|l|r|l|l|l|r|}
\hline & \multicolumn{1}{|l|}{$\mathbf{2 0 0 2}$} & $\mathbf{2 0 1 2}$ & $\mathbf{2 0 1 3}$ & $\mathbf{2 0 1 4}$ & \multicolumn{1}{|l|}{$\mathbf{2 0 1 5}$} \\
\hline Sağlık Bakanlığı & 1.072 .417 & 2.298 .893 & 2.414 .538 & 2.445 .424 & 2.364 .595 \\
\hline Üniversite & 307.108 & 664.695 & 715.889 & 765.549 & 801.424 \\
\hline Özel & 218.837 & 1.446 .630 & 1.553 .810 & 1.587 .973 & 1.604 .126 \\
\hline Toplam & 1.598 .362 & 4.410 .218 & 4.684 .237 & 4.798 .946 & 4.770 .145 \\
\hline
\end{tabular}

Kaynak: Sağlık İstatistikleri Yı1lığı, 2015

\footnotetext{
${ }^{6}$ Manyetik Rezonans

${ }^{7}$ Bilgisayarlı Tomografi

${ }^{8}$ Ekokargiyografi
} 
Öncelikle en çok dikkat çeken konu 2002 yılında Özel hastaneler için yapılan ameliyat sayılarının 2012 yılına gelindiğinde çarpıcı bir şekilde artış göstermesi olmuştur. Ardından göze en çok batan artışın Sağlık Bakanlığı hastaneleri olduğu görülmektedir. Toplam ameliyat oranlarının ise 10 yıl içinde neredeyse 3 katına çıkması biraz önce yukarıda belirtmiş olduğumuz iki soruyu tekrar aklımıza getirmektedir. Performansa dayalı ödeme sisteminin ameliyat oranlarında artışlara sebebiyet verdiği çıkarımı pek yanlış olmasa gerek. 2002 yılında toplam ameliyat oranı bir buçuk milyon dolaylarında iken 2015 yılında bu oran beş milyon civarına ulaşmıştır. Hürriyet gazetesinin bir haberine göre ise bu oranın 2014 yılı için 14 milyon 742 bin'e yükseldiği doğrultusundadır. Gene aynı haberde Türk Tabibler Birliği Genel Başkanı Beyazıt İlhan'ın bu durum üzerine yorumu; "Veriler her 5 kişiden birinin ameliyat olduğunu gösteriyor. Bu, öteden beri eleştirdiğimiz kamuda performans sistemi, özelde ciro baskısının sonucu. Bakanlık personeline düşük maaş veriyor ve 'gelirini yükseltmek istiyorsan çok muayene et, çok ameliyat yap' diyor." şekilde olmuştur (Hürriyet, 03.05.2015). Görüldüğü üzere performansa dayalı ödeme sistemi nedeniyle gerek devlet tarafından gerekse hekimler tarafından, halk gelir sağlayıcı olarak görülmektedir. Hekimlerin taban maaşlarında yaşanan düşüşleri işlem sayılarını arttırarak amorti etmeye çalışmaları halk üzerinde gerek maddi açıdan gerekse fizyolojik açıdan olumsuz sonuçlara yol açmaktadır.

Bir diğer değinilmesi gereken konu sağlık hakkı ihlalidir. Sağlık hakkı kişinin yaşama hakkı gibi ana rahmine düşmesiyle beraber başlamaktadır ve bu hak devlet tarafından koruma altına alınmalıdır. Sağlık hakkı, sosyal devlet anlayışı çerçevesinde değerlendirilmeli böylelikle kişiye devlet tarafından ücretsiz olarak sunulmalıdır. Ancak görmekteyiz ki devlet sağlık hakkını bireyin ellerinden almış küreselleşmeyle beraber, sermaye sisteminin daha çok beslenmesi amacıyla performansa dayalı ödeme sistemini sermayeye bahşetmiştir. Performans etki değerlemesini birde yatak doluluk oranları ile ölçmekte fayda vardır. Çünkü bir hastanın hastanede kalış süresi o hastanenin döner sermayesine gelen artı girdi anlamına gelmektedir. Aynı şekilde hastaya uygulanan tetkiklerde ilgili sağlık çalışanı için performans oranlarını arttırıcı etkiye sahiptir. Milliyet gazetesi tarafından yayınlanan bir habere göre bu durum biraz daha mikro ölçekli değerlendirilerek Aydın ili için yapılan işlem sayıları karşılaştırmaları Aydın Tabip odası başkanı Dr. Metin Aydın tarafından şu şekilde yapılmıştır; "polikliniklerde bakılan hasta sayısı \%3, acilde bakılan hasta sayısı \%16, yatak 
doluluk oranları \%14 artmıştır. Günübirlik ameliyat sayıları \%6'dan \%46’ya çıkmış fakat ă̆ır ciddi ameliyat sayıları \%34'den \%22'ye gerilemiş, hastanelerde ortalama kalış gün sayısı ise 3,8 olmuştur."(Milliyet, 26 Ocak 2015). Yerel bir değerlendirme yapılsa da aslında genel tablonun açık göstergesi niteliğinde bir özellik taşımaktadır. Aydın ili nüfus artış oranı açısından 2013-2014 yılı için \%2 oranında bir artış gösterdiğini göz önüne alırsak yukarıda verilen oranları daha anlamlı yorumlayabiliriz. $\mathrm{Bu}$ durumu özelden genele vurmamıza yardımcı olması açısından Türkiye geneli 2002-2015 yılları arasında yaşanan hastanelerde yatılan gün sayılarını vermek daha doğru olacaktır. Tablo 6'da bu konuya ilişskin bilgilere yer verilecektir.

Tablo 6: Y1llara ve Sektörlere Göre Hastanelerde Yatılan Gün Sayısı, Türkiye

\begin{tabular}{|l|r|r|r|r|l|}
\hline & \multicolumn{1}{|l|}{$\mathbf{2 0 0 2}$} & $\mathbf{2 0 1 2}$ & $\mathbf{2 0 1 3}$ & $\mathbf{2 0 1 4}$ & $\mathbf{2 0 1 5}$ \\
\hline Sağlık Bakanlığı & \multicolumn{1}{|c|}{23.770 .910} & 29.662 .436 & 30.679 .607 & 32.078 .874 & 32.011 .141 \\
\hline Üniversite & 6.713 .945 & 9.846 .341 & 9.753 .138 & 10.260 .691 & 10.575 .334 \\
\hline Özel & 1.730 .661 & 8.001 .322 & 8.247 .245 & 9.521 .899 & 10.649 .770 \\
\hline Toplam & 32.215 .516 & 47.510 .099 & 48.679 .990 & 51.861 .464 & 53.236 .245 \\
\hline
\end{tabular}

Kaynak: Sağlık İstatistikleri Yıllığı, 2015

Tablo 6'ya baktığınız zaman 13 yılda yaşanan artışın en fazla özel hastanede yatılan gün sayısında yaşandığını ve ikinci sırada bakanlık hastanelerinin olduğunu görebilirsiniz. Toplam olarak değerlendirmek gerekirse yalnızca 13 yıl için \%65 oranında bir artış yaşanmıştır. Hastane kalış gün sayılarının fazlalıkları hastane personelleri açısından daha yoğun çalışma temposuna itilmek anlamına gelmektedir. Bu denli hasta akışına maruz kalmak sağlık personellerini yabancılaşmaya itmekle beraber halk açısından daha fazla sağlık harcamas1 yapılması anlamına gelmektedir.

Son olarak değerlendirmeye alacağımız tablo 7'de yıllara göre ilaç tüketim miktarını milyon kutu değerinde inceleyeceğiz. Bilindiği üzere kişinin sağlığının korunması ve kaybedilen sağlığın geri kazanımı doğru beslenme ve doğru hayat kalitesi ile ilişkilendirilmektedir. Eğer birey sağlığını kaybederse sağlığını geri kazanmak için önemli düzeyde çaba harcaması gerekmektedir. Bu durum ise finansal kudretle doğru orantılıdır. Tedavi edici sağlık harcamaları koruyucu sağlık harcamalarına göre daha az maliyet ve daha az psikolojik tahribatı içerisinde barındırır. Bu nedenle koruyucu sağlık hizmetlerinin önemi 
gerek sosyal devlet anlayışı içerisinde gerekse bireyin kendi yaşam ahlakı açısından hiç bir zaman yitirilmeyecektir. Sağglığını kaybeden kişiler hekimlerin önerisiyle ilaçlara başvurarak eski sağlıklarına kavuşmaya çalışmaktadırlar ama göz ardı edilmemesi gereken önemli bir şey vardır ki o da insanların sağlı̆̆ının bir sektör olan ilaç sektörüne bağlı olmasıdır.

Tablo 7: Yı1lara Göre İlaçların Tüketim Miktarı (Milyon Kutu), Türkiye

\begin{tabular}{|l|c|l|l|}
\hline Yillar & Toplam & $\mathbf{2 0 0 9}$ & $1.531,5$ \\
\hline $\mathbf{2 0 0 3}$ & 768,9 & $\mathbf{2 0 1 0}$ & $1.669,90$ \\
\hline $\mathbf{2 0 0 4}$ & 855,7 & $\mathbf{2 0 1 1}$ & $1.848,30$ \\
\hline $\mathbf{2 0 0 5}$ & $1.212,1$ & $\mathbf{2 0 1 2}$ & $1.889,40$ \\
\hline $\mathbf{2 0 0 6}$ & $1.292,1$ & $\mathbf{2 0 1 3}$ & $1.912,20$ \\
\hline $\mathbf{2 0 0 7}$ & $1.398,9$ & $\mathbf{2 0 1 4}$ & $1.969,97$ \\
\hline $\mathbf{2 0 0 8}$ & $1.476,6$ & $\mathbf{2 0 1 5}$ & $2.112,94$ \\
\hline
\end{tabular}

Kaynak: Sağlık İstatistikleri Yı1lığı 2009; 2015

Tablo 7 yıllara göre ilaç tüketim oranlarını göstermektedir. Tabloya baktığımızda her geçen yıl ilaç tüketim oranlarında önemli bir artış yaşandığını görülmektedir. İlk olarak hızla artan sağlık problemlerinin temel kaynağ koruyucu ve önleyici sağlık hizmetlerinin doğru bir şekilde yürütülmemesinden kaynaklıdır ve yukarıda birinci basamak sağlık kuruluşlarının etkin bir şekilde hizmet sunumu sağlayamadığını görmüştük. İkinci olarak ise doktorlar ve ilaç şirketleri arasından kurulan farklı bağlardan oluşabilmektedir. Bu durumu Belek (2004:246) bizlere şöyle aktarmıştır; ilaç araştırmalarını yürüten firmalar neredeyse tekelleşmiş bir vaziyettedir ve bu ilaç firmaları ilaç tüketimini kontrolsüz bir şekilde arttırmayı hedeflemektedir. Türkiye'de mevcut pazarda bulunan ilaçların belli oranda yazılıp tüketiminin sağlanması karşılı̆̆ında firmalar tarafindan doktorlara fahişe bile pazarlanmaktadır. Gizli bir anlaşmaya dönen ilaç reçeteleşme sistemi böylelikle daha çok ilaç tüketimini arttırmıştır. Bir diğer gizli anlaşma türünü ise yine daha önce belirtildiği üzere Sağlık Bakanı'nın yaptığı konuşmada görmekteyiz. Performansa dayalı ödeme sistemi hakkında yapmış olduğu açıklamada doktorların daha fazla işlem, daha fazla hasta memnuniyeti sağlamaları doğrultusunda performans değerlemelerinde puanlarının o kadar artacağ1 yönündeydi. Böylelikle daha çok kazanmak isteyen hekim, gereklilik koşuluna bakmadan daha çok ilaç reçeteleme yoluna girmektedir. 


\section{SONUÇ YERINE}

Türkiye, sağlıkta dönüşüm sürecine hızlı bir şekilde girmiştir. $\mathrm{Bu}$ hızlı ivme sağlık çalışanları ve hastalar üzerinde ciddi olarak olumsuz sonuçlar doğurmuş, hasta doktor ilişkisi, müşteri ve hizmet sunucu olarak şekil değiştirmiştir. 2007 yılında birinci basamakların sevk sistemi uygulaması kaldırılarak hastalara diledikleri sağlık basamaklarına istedikleri zaman girip çıkma hakkı tanınmıştır. Bunun sonucu olarak ciddi tetkik ve tedavi yürütümü uygulayan 2. ve 3. basamak sağlık kurumları yoğun hasta giriş çıkışına maruz kalmıştır. Doktorların performansa dayalı ücretlendirme sistemine tabi tutulmaları hastaları muayene sürelerini kısaltmış daha çok hastayı gün içerisinde muayene etmeye çalışmıştır. Hem hasta yoğunluğu hem daha çok hastayı kontrol etme çabaları ciddi rahatsızlığı olan hastaların verimli tedavi sürecini engellemektedir. Verilen istatistikler doğrultusunda sağlikta dönüşümün ilk amacı olan herkese adil sağlık hizmeti, önleyici ve koruyucu sağlık hizmeti yaygınlığı politikalarının işlevini yürütemediğini görmekteyiz. Kamu kuruluşlarının özel sektör kurallarıyla yönetilmesi, çalışanlar açısından kamu ve özel sektör arasındaki sınırın ortadan kaldırmaya başlamıştır. Öte yandan özel sağlık kuruluşlarında sayıları giderek artan sağlık çalışanları çok daha güvencesiz ve örgütsüz bir ortamda çalışmaktadır. Sağlık hizmetlerinde piyasalaşmayla esnek çalışma biçimleri, uzun çalışma saatleri ve düşük ücret gibi uygulamalar gündeme gelmiştir. Kamu hastanelerinde güvencesiz çalışma biçimleri yaygınlaşmış böylece devlet memuru statüsünün avantajları sağlık çalışanları için kayıplarla sonuçlanmıştır. Hastalar açısından değerlendirmek gerekirse, her geçen gün artan sağlık harcamaları altında ezilmektedirler, ücretsiz adı altında sunulan sağlık hizmetlerinin giderleri halk tarafından her aşamada temin edilmektedir. Özetlemek gerekirse sağlıkta yapılan reform uygulamaları, sağlık çalışanlarını vasıfsızlaştırmış ve neoliberal ekonomi sistemi mantığı tamamen sağlık hizmetlerine uyumlaştırılmıştır.

\section{KAYNAKÇA}

Aka A., Kablay S. ve Demir Cem M. (2012), Neoliberal Politikalar ve Sağllk Çalışanları, Ankara: Nobel. 
Akdağ R., (2012), Türkiye Sağlıkta Dönüşüm Programı Değerlendirme Raporu 20032011, Sağlık Bakanlığı Yayınları.

Akdur R. (1999), Türkiye’de Sağlık Hizmetleri ve Avrupa Topluluğu Ülkeleri ile Klyaslanması, Ankara: Ankara Üniversitesi

Akpınar Talip A. ve Taş Y. (2013), "Performansa Dayalı Ek Ödeme Sistemine İlişkin Hekimlerin Tutumları Üzerine Kocaeli Üniversitesi Araştırma ve Uygulama Hastanesi’nde Bir Araştırma", Çalışma ve Toplum, 2, 167-181.

Alper Y. (2014), Türk Sosyal Güvenlik Sistemi Sosyal Sigortalar Hukuku, 6. Baskı, Bursa: Dora Yayınevi.

Ataay F. (2008), "Sağlık Reformu ve Yurttaşlık Hakları", Amme İdaresi Dergisi, 41(3), 169-184.

Aydın, M. (2015), "Yöneticiler Başarı Hastalar Can Derdinde” Milliyet Gazetesi, Ocak 2015, $\quad$ http://www.milliyet.com.tr/dr-aydin-yoneticiler-basari-hastalar-aydin-yerelhaber-

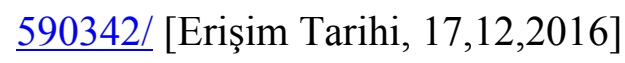

Belek İ. (2004), Esnek Üretim Derin Sömürü, İstanbul: NK Yayınları.

Çelikay F. Ve Gümüş E. (2011), "Sağlıkta Dönüşümün Ampirik Analizi”, SBF Dergisi, 66(3), 55-92.

Ekin A. (2012), “ Genel Sağlık Sigortasından Yararlanma Şartları ve Esasları”, TTB Dergisi, 100, 151-166.

Er Ü. (2011), Sağlıkta Dönüşümün Aracı Genel Sağllk Sigortası, Ankara: Ankara Üniverstesi Sosyal Bilimler Enstitüsü Yüksek Lisans Tezi.

Esen, B. (2013), “Eczanelerden İlaç Alırken Aile Hekimlerinde Katılım Payı Var Mi?”, http://www.ailehekimleri.net/index.php/haberler/haberleri/82-ulusal/7578-eczanedenilac-alrken-aile-hekimlerinde-katlm-pay-var-m [Erişim Tarihi, 17.12.2016] 
İçli G. "Küreselleşme ve Sınıf”, Küreselleşen Dünyada Değişimin Farklı Yüzleri Disiplinler Arası Bir Yaklaşım, N. Sam ve R. Sam (edt), 369-391, Bursa: Ezgi Kitabevi.

Kablay S., (2011), “Sağlık Alanında Uygulanan Ücret Politikalarının Bir Aracı Olarak Döner Sermaye Primi Uygulamaları", 2000'li Yıllarda Türkiye'de İktisat ve Siyaset Rüzgarlarl, Ö. Birler vd. (Der.), 49-69.

Kablay S., (2014), "Performansa Dayalı Döner Sermaye Primi Uygulaması ve Sağlık Çalışanlarına Etkisi”, İş Güç Endüstri İlişkileri ve İnsan Kaynakları Dergisi, 6(4), 85-110.

Önder vd. (2011), “Ankara Numune Eğitim ve Araştırma Hastanesinde Çalışan Hekim ve Hemşirelerin Geçirdikleri İş Kazaları ve Meslek Hastalıkları Yönünden Değerlendirilmesi”, Ankara Üniversitesi Dikimevi Sağllk Hizmetleri Meslek Yüksekokulu Dergisi, 10(1), 31-44.

Özgenç, M. (2015), “Ameliyat Sayısında Rekor Artış”, Hürriyet Gazetesi, Haziran 2015,http://www.hurriyet.com.tr/ameliyat-sayisinda-rekor-artis-29179339 [Erişim Tarihi, 17.12.2016]

Sağlık Araştırmaları Genel Müdürlüğü (2013), Să̆lık Bakanlı̆̆ı Săglık İstatistikleri Yıllı̆̆ı 2012, Ankara: Sentez Matbaacılık.

Sağlık Araştırmaları Genel Müdürlüğü (2016), Să̆lık Bakanlığı Să̆lık Istatistikleri Yıllı̆̆ 2015, Ankara: Sistem Ofset.

Sayan-Özkal, İ. ve Küçük, A. (2012), “Türkiye’de Kamu Personeli İstihdamında Dönüşüm: Sağlık Bakanlığı Örneği”, Ankara Üniversitesi SBF Dergisi, 67(1), 171-203.

Soyer, A., (2007), “Tam Gün Kimin İçin?”, Evrensel Gazetesi, Ekim 2007, http://sendika10.org/2007/10/tam-gun-kimin-icin-ata-soyer-evrensel// [Erişim Tarihi, 27.05.2016]

Şahin E. Ç. (2011), Beşeri Sermaye ve İnsan Kaynakları Eleştirel Bir Yaklaşım, Ankara: Tan Yayınları. 
Türkiye Cumhuriyeti Sağlık Bakanlığı Refik Saydam Hıfzıssıhha Merkezi Başkanlığı

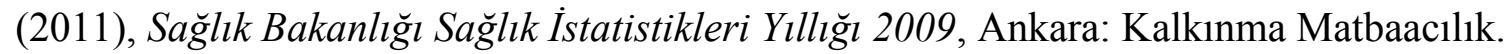

Türkiye İstatistik Kurumu (TÜİK), Demografik Göstergeler 2000-2023.

Ulutaş-Ünlütürk Ç. (2011), Proleterleşme ve Profesyonelleşme Tartışmalardı Işı̆ğında Türkiye’de Sağlık Emek Sürecinin Dönüşümü, Ankara:Notabene Yatınları. 